\title{
ANTIMICROBIAL ACTIVITY OF COPAIFERA SPP. AGAINST BACTERIA ISOLATED FROM MILK OF COWS WITH MASTITIS
}

\section{ATIVIDADE ANTIMICROBIANA DE COPAIFERA SPP. FRENTE ÀS BACTÉRIAS ISOLADAS DE LEITE DE VACAS COM MASTITE}

\author{
Maria Juíva Marques de Faria ${ }^{1}$ \\ Carla Afonso da Silva Bitencourt Braga ${ }^{1^{*}}$ \\ José Realino de Paula ${ }^{1}$ \\ Maria Cláudia Dantas Porfírio Borges André ${ }^{1}$ \\ Boniek Gontijo Vaz ${ }^{1}$ \\ Thays Colletes de Carvalho ${ }^{1}$ \\ Wanderson Romão \\ Helber Barcellos da Costa ${ }^{2}$ \\ Edemilson Cardoso da Conceição ${ }^{1}$ \\ ${ }^{1}$ Universidade Federal de Goiás, Goiânia, GO, Brazil. \\ ${ }^{2}$ Universidade Federal do Espírito Santo, Vitória, ES, Brazil. \\ *Author for Correspondence - carlaafonsoufg@gmail.com
}

\begin{abstract}
The antimicrobial activities of the oleoresin (OR) and the essential oil (EO) of Copaifera spp. were checked against microorganisms isolated from milk samples of cows diagnosed with grade III subclinical mastitis. The OR had good antimicrobial activity (MIC $\leq 100 \mu \mathrm{g} / \mathrm{mL}$ ) against samples of coagulase-positive Staphylococcus, coagulase-negative Staphylococcus, Streptococcus of groups C, F, and G, and Corynebacterium spp. Meanwhile, the EO had good antimicrobial activity (MIC $\leq 100$ $\mu \mathrm{g} / \mathrm{mL}$ ) against coagulase-negative Staphylococcus and Corynebacterium spp. The OR and the EO were inactive and weak to inactive, respectively, against Escherichia coli. Overall, the OR had better antimicrobial activity than the essential oil against the 55 bacterial isolates $(p<0.0001)$. The GC/MS analysis identified sesquiterpenes in EO and by the ESI FT-ICR MS method, the identification of diterpenic acids in OR was possible. Therefore, this raw plant material is promising for the development of phytotherapeutic drugs against bovine mastitis.
\end{abstract}

Keywords: bovine mastites; ESI FT-ICR MS; essential oil; minimum inhibitory concentration; oleoresin.

\section{Resumo}

A mastite bovina é um problema sanitário que afeta o gado leiteiro em todas as áreas produtoras do 
mundo, sendo de difícil controle e erradicação. A atividade antimicrobiana da oleorresina e do óleo essencial de Copaifera spp. foi verificada frente aos micro-organismos isolados de amostras de leite de vacas diagnosticadas com mastite subclínica grau III. A oleorresina de Copaifera ssp. apresentou boa atividade antimicrobiana $(\mathrm{CIM} \leq 100 \mu \mathrm{g} / \mathrm{mL})$ frente às amostras de Staphylococcus coagulase positivo, Staphylococcus coagulase negativo, Streptococcus do grupo C, F, G e Corynebacterium spp. Já o óleo essencial de Copaifera spp. apresentou boa atividade antimicrobiana (CIM $\leq 100$ $\mu \mathrm{g} / \mathrm{mL}$ ) frente aos Staphylococcus coagulase negativo e Corynebacterium spp. Em relação à Escherichia coli, a atividade antimicrobiana da oleorresina e o óleo essencial foi inativa e fraca à inativa, respectivamente. Conclui-se que, frente às 55 bactérias isoladas, a olerresina apresentou melhor atividade antimicrobiana do que o óleo essencial de Copaifera spp. ( $<<0,0001)$. A análise por CG/EM identificou sesquiterpenos no óleo essencial e pelo método ESI FT-ICR MS, foi possível identificar ácidos diterpenos na oleorresina de Copaifera spp. Por fim, sugere-se que a oleorresina de Copaifera spp. é uma matéria-prima vegetal promissora no desenvolvimento de medicamento fitoterápico para o tratamento de mastite bovina.

Palavras-chave: concentração inibitória mínima; ESI FT-ICR MS; mastite bovina; óleo essencial; oleorresina.

Received on December, $15^{\text {th }} 2015$.

Accepted on October, $19^{\text {th }} 2016$.

\section{Introduction}

Bovine mastitis, or mammitis, is a sanitary problem that affects dairy cattle throughout the world and is hard to control and eradicate ${ }^{(1)}$. Mastitis is an inflammatory process of the mammary gland, usually infectious. Different etiological agents may cause the disease, although bacteria represent the most common origin ${ }^{(2)}$.

Depending on its manifestation, this disease can be classified as clinical or subclinical. In clinical mastitis, there are visible signs of inflammation in the udder and macroscopic abnormalities in the milk $^{(3)}$. If the manifestation is subclinical, the inflammatory reactions are milder, and there are no visible alterations in the mammary glands and milk of the animal ${ }^{(4)}$. In this case, diagnosis depends on complementary exams, such as the California Mastitis Test (CMT). Depending on the level of reaction, the mastitis may be classified into grades I, II, or III ${ }^{(5)}$.

Mastitis can also be classified as contagious or environmental, based on the type of pathogen. Microorganisms in genera Staphylococcus, Streptococcus, Corynebacterium, and Mycoplasma cause contagious mastitis. In contrast, the microorganisms present in the environment occupied by the animal ${ }^{(4)}$, such as coliform bacteria (Escherichia coli), Streptococcus uberis, Actinomyces pyogenes, Pseudomonas spp., fungi, algae, and viruses ${ }^{(6)}$ cause environmental mastitis. One of the main etiological agents, both in Brazil and in other countries, is Staphylococcus aureus ${ }^{(7)}$.

Etiological agents are becoming resistant to the antibiotics used to treat bovine mastitis, and cure rates from conventional treatments are low. As a result, alternative methods are increasingly being sought to circumvent this problem ${ }^{(8,9)}$. 
There are many medicinal plants in the Cerrado biome that are used traditionally and are scientifically proven to have antimicrobial activity. Among those we can find copaiba trees, which are native to tropical regions of Latin America and West Africa and include 72 species, 16 of those endemic to Brazil ${ }^{(10)}$. Copaiba trees belong to genus Copaifera, family Leguminosae, subfamily Caesalpinioideae. The oleoresin, extracted sustainably from the trunk, is an exudate composed of resin acids (diterpenes) and volatile compounds (sesquiterpenes), which are responsible for its antimicrobial, wound healing, and anti-inflammatory pharmacological properties ${ }^{(10-13)}$.

Previous studies have shown that the copaiba exudate inhibits the growth of the bacteria $S$. aureus, E. coli, and Pseudomonas aeruginosa ${ }^{(14)}$, in addition to bacteria in genus Streptococcus ${ }^{(15)}$. According to Santos et al. ${ }^{(16)}$, the oleoresin acts on the cell wall of Gram-positive bacteria, causing ruptures, loss of cytoplasmic compounds and even loss of cell wall, altering cell morphology and reducing its volume. However, Deus et al. ${ }^{(17)}$ demonstrated the essential oil of Copaifera multijuga had better antifungal properties against Aspergillus flavus and Candida parapsilosis than the oleoresin.

Furthermore, the study developed by Bulgacov et. al. ${ }^{(18)}$ to test copaiba oil creams effectiveness against Staphylococcus spp. isolated from cases of subclinical mastitis in 79 teats of lactating cows verified positive results in $94.93 \%$ (75/79) of samples.

The goal of the present study was to evaluate the antimicrobial activity of the oleoresin and the essential oil of Copaifera spp. against microorganisms isolated from grade III subclinical bovine mastitis and identify diterpenic acids and sesquiterpenes in oleoresin (OR) and essential oil (EO) of Copaifera spp., respectively.

\section{Material and Methods}

1. Plant material: The unique OR pool of Copaifera spp. sample was purchased in June 2012 from Nutragyn Indústria de Alimentos Ltda (Goiânia, GO, BRA) and stored in amber vials kept at room temperature.

2. Cultivation media: All cultivation media (mannitol salt agar, MacConkey agar, Sabouraud agar, and agar base) were obtained from ISOFAR Indústria e Comércio de Produtos Químicos Ltda (Duque de Caxias, RJ, Brazil).

3. Identification of diterpenes present in OR of copaifera spp. by electrospray ionization of fourie transformed ionic cyclotron resonance mass spectrometry (ESI FT-ICR MS): The OR of Copaifera spp. sample was diluted to $\approx 0.25 \mathrm{mg} / \mathrm{mL}$ in water:methanol $(1: 1)$ that contained $0.1 \% \mathrm{v} / \mathrm{v}$ of $\mathrm{NH}_{4} \mathrm{OH}$ for electrospray (ESI) in negative mode, ESI (-). The resulting solution was directly infused at a flow rate of 5 $\mu \mathrm{L} / \mathrm{min}$ into the ESI source. The mass spectrometer (model 9.4 T Solarix, Bruker Daltonics, Bremen, Germany) was set to operate over a mass range of $m / z$ 150-500. The ESI source conditions were as follows: a nebulizer gas pressure of $3 \mathrm{bar}$, a capillary voltage of $3.5 \mathrm{kV}$, and a transfer capillary temperature of $250{ }^{\circ} \mathrm{C}$. The ions were accumulated in the hexapolar collision cell with time of $5.10^{-3} \mathrm{~s}$ followed by transport to the analyzer cell (ICR) through the multipole ion guide system (another hexapole). The time-of-flight in the hexapole was of $0.7 \mathrm{~ms}$. Each spectrum was acquired by accumulating 32 scans of time-domain transient signals in 8 mega-point time-domain data sets. All mass spectra were externally calibrated using NaTFA. A resolving power, $\mathrm{m} / \Delta \mathrm{m}_{50 \%} \cong 500000$, in which $\Delta \mathrm{m}_{50 \%}$ is the full peak width at half-maximum peak height of $m / z \cong 400$ and a mass accuracy of $<1 \mathrm{ppm}$ provided the unambiguous molecular formula assignments for 
singly charged molecular ions. The mass spectrum was acquired and processed using Data Analysis software (Bruker Daltonics, Bremen, Germany). The MS data was processed, and the elemental compositions of the compounds were determined by measuring the $\mathrm{m} / \mathrm{z}$ values ${ }^{(19)}$. The proposed structures for each formula were assigned using the chemspider (www.chemspider.com) database and also following the study by Veiga Júnior and Pinto ${ }^{(10)}$.

4. Extraction and chemical analysis of the volatile fraction: The volatile fraction was obtained from the OR of Copaifera spp. by hydrodistillation in a Clevenger-type apparatus for 4 hours. We used a Shimadzu QP 5050A instrument with a fused silica capillary column CBP-5 (30 $\mathrm{m} \times 0.25 \mathrm{~mm} \times 0.25 \mu \mathrm{m})$ for gas chromatography coupled with mass spectrometry (GC/MS) analyses. Helium was used as carrier gas at a constant flow rate of $1.0 \mathrm{~mL} / \mathrm{min}$ and initial temperature of $60^{\circ} \mathrm{C}$ for 2 minutes, followed by heating at $3{ }^{\circ} \mathrm{C} / \mathrm{min}$ up to $240{ }^{\circ} \mathrm{C}, 10^{\circ} \mathrm{C} / \mathrm{min}$ up to $280^{\circ} \mathrm{C}$, and constant temperature of $280{ }^{\circ} \mathrm{C}$ for 10 minutes. The ionization energy was $70 \mathrm{eV}$. The injection volume was $1 \mu \mathrm{L}$ of the diluted sample of dichloromethane (Vetec Química Fina LTDA, Duque de Caxias, RJ, Brazil) at a 1:5 ratio. Individual components of the EO were identified by comparison of mass spectra, and retention indices were calculated from a linear sequence of n-alkanes $\mathrm{C} 8-\mathrm{C} 36^{(20)}$.

5. Phenotypic characterization of microorganisms isolated from grade III subclinical bovine mastitis: The study was approved by the ethics committee of Universidade Federal de Goiás (UFG) under the protocol number 063/12. Milk samples were collected from farms near Goiânia in August 2012 and February 2013. Among the three properties, two of them performed mechanical milking and one manual milking, twice a day, with an average interval of 10-12 hours. It is noteworthy that animal productivity was $30 \mathrm{~L} /$ day on average. Before milking, teats were washed with water, and a strip cup was used to test the animals for clinical mastitis. Mammary quarters without clinical mastitis were subjected to the CMT test (Tadabras Indústria e Comércio de Produtos Agroveterinários Ltda, Bragança Paulista, SP, Brazil) to detect subclinical mastitis $^{(5)}$. After the evaluation by the CMT test and the antisepsis with $70 \%$ alcohol (Vetec Química Fina LTDA, Duque de Caxias, RJ, Brazil), the first three squirts of teats diagnosed with grade III subclinical mastitis were discarded, and $10 \mathrm{~mL}$ of milk were collected in sterilized glass tubes and immediately transported to the Bacteriology Laboratory of the Tropical Pathology and Public Heath Institute (IPTSP) of UFG. Samples were plated on mannitol salt agar, MacConkey agar, Sabouraud agar supplemented with $0.05 \%$ chloramphenicol, and agar base supplemented with $5 \%$ defibrinated horse blood, following Winn et al. ${ }^{(21)}$. Morphotypes were separated based on morphology and staining traits, isolated and identified following Baron et al. ${ }^{(22)}$, Brasil ${ }^{(23)}$, and Winn et al. ${ }^{(21)}$. Standard strains of S. aureus ATCC 25923, Pseudomonas aeruginosa ATCC 27853, Proteus vulgaris ATCC 13315, and E. coli ATCC 8739, obtained from IPSTP/UFG, were used as controls. After identification, microorganisms were added to Eppendorf tubes containing tryptic soy broth (TSB) and 20\% glycerol (Vetec Química Fina LTDA, Duque de Caxias, RJ, Brazil) and stored at $-20^{\circ} \mathrm{C}$.

6. In-vitro antimicrobial activity: The minimum inhibitory concentrations (MIC) of the OR and the EO of Copaifera spp. against isolated microorganisms were determined using microdilution in Mueller-Hinton broth $(\mathrm{MH})$, following the protocol of the Clinical and Laboratory Standards Institute ${ }^{(24)}$. Sterile U-bottom 96-well microplates were used. We added $200 \mu \mathrm{L}$ of OR with a concentration of $2000 \mu \mathrm{g} / \mathrm{mL}$ to the first column. Next, $100 \mu \mathrm{L}$ were extracted from the first column and transferred to the second. This step was repeated for each successive column to obtain a serial microdilution. The final concentration of the last column was $1.95 \mu \mathrm{g} / \mathrm{mL}$. The same procedure was used for the EO. Afterward, the inoculants were added. They were prepared to a turbidity of a $0.5 \mathrm{McF}$ arland standard $\left(10^{7}\right.$ bacterial cells $)$, obtained by reading a spectrophotometer at $625 \mathrm{~nm}(0.08$ to 0.10 absorbance) and diluted at 1:10 for the broth microdilution procedure. Inoculations were carried out in duplicate. The $\mathrm{MH}$ broth of fastidious organisms was supplemented with 5\% lysed horse blood, added before the microorganism was inoculated to avoid additional dilution of the antimicrobial agents in the microplates. Microplates were incubated at $37{ }^{\circ} \mathrm{C}$, and the MIC was read after 24 hours using 0.5\% triphenyl tetrazolium chloride (TTC) (Vetec Química Fina 
LTDA, Duque de Caxias, RJ, Brazil). The MIC was defined as the lowest concentration of OR or EO of Copaifera spp. that inhibited microbial growth. Following Holetz et al. ${ }^{(25)}$, the antimicrobial activity was considered good for MIC values $\leq 100 \mu \mathrm{g} / \mathrm{mL}$, moderate for $100<\mathrm{MIC} \leq 500 \mu \mathrm{g} / \mathrm{mL}$, weak for $500<\mathrm{MIC} \leq 1000 \mu \mathrm{g} / \mathrm{mL}$, and inactive for MIC values above $1000 \mu \mathrm{g} / \mathrm{mL}$.

7. Statistical analysis: We analyzed frequency data from the phenotypic characterization of microorganisms and from the antimicrobial activities of OR and EO against bacterial isolates. A Wilcoxon non-parametric test was used to compare the activities of the OR and the EO, using the NPAR1WAY procedure in SAS at a significance level of 5\%.

\section{Results}

By the ESI FT-ICR MS method, we identified the diterpenic acids in OR of Copaifera spp. Figure 1 shows mass spectrum, in the negative mode-ESI (-), of compounds present in OR samples from Copaifera spp. Table 1 contains molecular formula estimated in the ESI FT-ICR MS and diterpenes present in them.

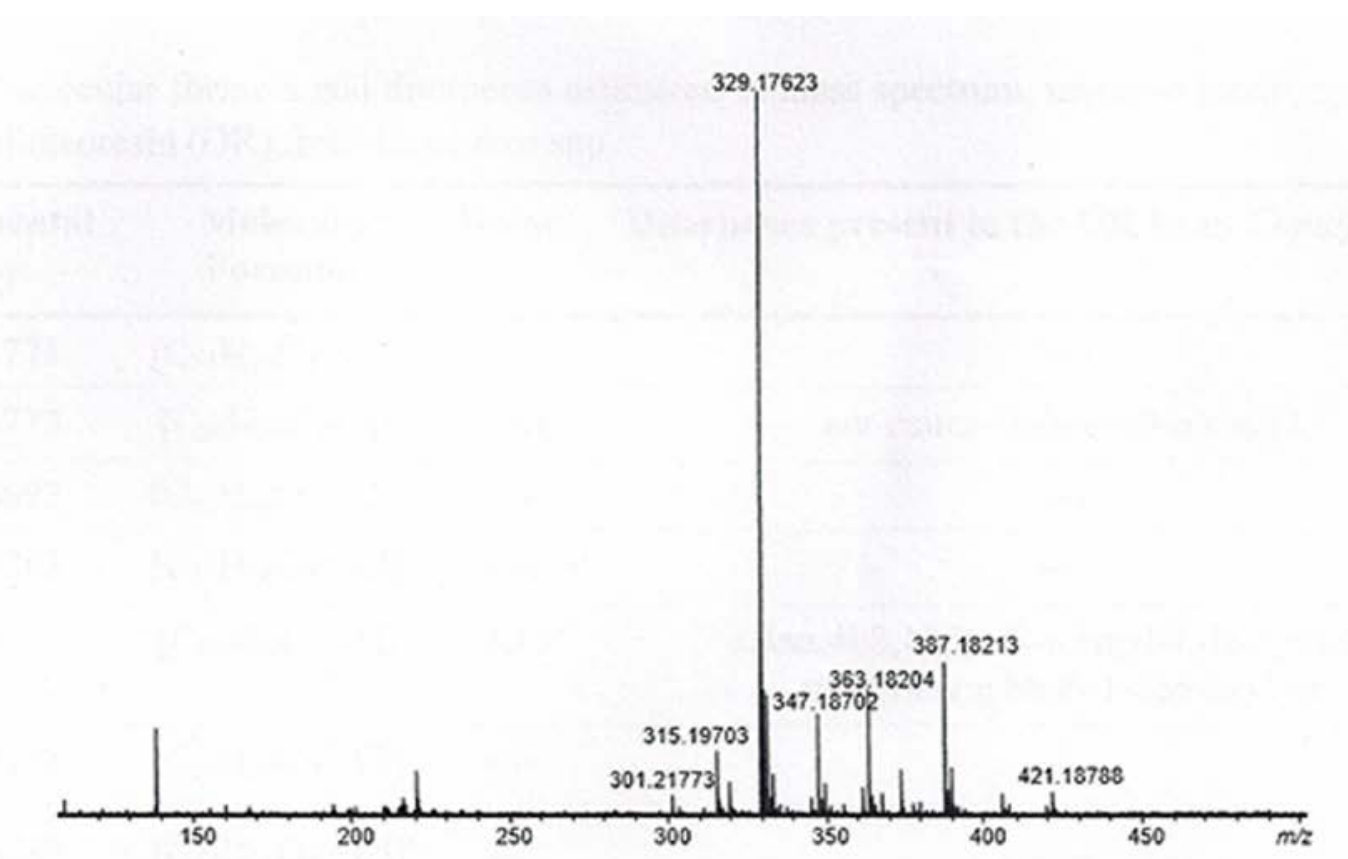

Figure 1. Mass spectrum, in negative mode, by ESI(-) FT-ICR MS, of OR from Copaifera spp. 
Table 1. Molecular formula and diterpenes estimated in mass spectrum, negative mode, by ESI(-) FTICR MS of oleoresin (OR) from Copaifera spp

\begin{tabular}{|c|c|c|c|}
\hline $\begin{array}{l}\text { Experimental } \\
(m / z)\end{array}$ & $\begin{array}{l}\text { Molecular } \\
\text { Formula }\end{array}$ & Error & Diterpenes present in the $\mathrm{OR}$ from Copaifera spp. \\
\hline 289.15771 & {$\left[\mathrm{C}_{15} \mathrm{H}_{26} \mathrm{O}_{3}+\mathrm{Cl}\right]^{-}$} & $\cdots$ & $\cdots$ \\
\hline 301.21773 & {$\left[\mathrm{C}_{20} \mathrm{H}_{30} \mathrm{O}_{2}-\mathrm{H}\right]^{*}$} & $-1,41$ & ent-caura-16-eno-19-oic acid \\
\hline 303.13697 & {$\left[\mathrm{C}_{15} \mathrm{H}_{24} \mathrm{O}_{4}+\mathrm{Cl}\right]^{-}$} & $\cdots$ & $\cdots$ \\
\hline 305.15263 & {$\left[\mathrm{C}_{15} \mathrm{H}_{26} \mathrm{O}_{4}+\mathrm{Cl}\right]^{-}$} & $\cdots$ & $\cdots$ \\
\hline 315.19703 & {$\left[\mathrm{C}_{20} \mathrm{H}_{27} \mathrm{O}_{3}-\mathrm{H}^{-}\right.$} & $-1,43$ & $\begin{array}{l}(1 \alpha, 4 \mathrm{a} \alpha, 4 \mathrm{~b} \beta, 10 \beta) \text {-10-formyl-1,4a-dymetyl-8- } \\
\text { methylenegibban-1-carboxylate }\end{array}$ \\
\hline 319.13188 & {$\left[\mathrm{C}_{15} \mathrm{H}_{24} \mathrm{O}_{5}+\mathrm{Cl}\right]^{-}$} & $-\cdots$ & $\cdots$ \\
\hline 321.14757 & {$\left[\mathrm{C}_{15} \mathrm{H}_{26} \mathrm{O}_{5}+\mathrm{Cl}\right]$} & --- & $\cdots$ \\
\hline 329.17623 & {$\left[\mathrm{C}_{20} \mathrm{H}_{25} \mathrm{O}_{4}-\mathrm{H}\right]^{-}$} & $-1,22$ & {$[(17 \beta)-3,17$ - dyhydroxyestra-1(10),2,4-trien-17-yl] acetate } \\
\hline 333.11122 & {$\left[\mathrm{C}_{15} \mathrm{H}_{22} \mathrm{O}_{6}+\mathrm{Cl}\right]^{-}$} & $\cdots$ & $\cdots$ \\
\hline 333.20727 & {$\left[\mathrm{C}_{20} \mathrm{H}_{30} \mathrm{O}_{4}-\mathrm{H}\right]^{\cdot}$} & $--\cdot$ & $\begin{array}{l}\text { ent-8(17),13-labdadiene-15,19-dioic acid (ent-agatic acid) } \\
\text { or 13-clerodene-15,16-olydeo-18-oic acid }\end{array}$ \\
\hline 347.18702 & {$\left[\mathrm{C}_{20} \mathrm{H}_{27} \mathrm{O}_{5}-\mathrm{H}\right]^{-}$} & $-1,08$ & $\begin{array}{c}\text { (4aR,5S,7R,8aS,9aS)- 8a-hydroxy-3,4a, 5-trymetyl-2- } \\
\text { oxo-2,4,4a,5,6,7,8,8a,9,9a-decahydronaphtho[2,3- } \\
\text { b] furane-7-yl (2E)-2-metyl-2-butenoate }\end{array}$ \\
\hline 363.18204 & {$\left[\mathrm{C}_{20} \mathrm{H}_{27} \mathrm{O}_{6}-\mathrm{H}\right]^{-}$} & $-2,02$ & $\begin{array}{l}\text { 1-formyl-3,7-dyhydroxy-4a-(hydroxymetyl)-1-metyl-8- } \\
\text { metylenegibbane-10-carboxylate }\end{array}$ \\
\hline 367.18151 & {$\left[\mathrm{C}_{20} \mathrm{H}_{28} \mathrm{O}_{4}+\mathrm{Cl}\right]^{-}$} & $-0,54$ & $\begin{array}{c}\text { 3,13-clerodadyene-15,16-olydeo-18-oic acid (patagonic } \\
\text { acid) or ent-15,16-epoxy-7 } 3 \text {-hydroxy-3,13(16),14- } \\
\text { clerodatryene-18-oic acid (7-hydroxy-hardwyckyyco } \\
\text { acid) }\end{array}$ \\
\hline 373.20276 & {$\left[\mathrm{C}_{22} \mathrm{H}_{29} \mathrm{O}_{5}-\mathrm{H}\right]^{*}$} & $-2,91$ & $\cdots$ \\
\hline 383.16329 & {$\left[\mathrm{C}_{20} \mathrm{H}_{28} \mathrm{O}_{5}+\mathrm{Cl}\right]$} & $-0,57$ & $\begin{array}{c}(5 \beta, 7 \alpha, 8 \alpha, 9 \beta, 10 \alpha, 13 \alpha, 14 \mathrm{R})-7,14-\text { dyhydroxy-15- } \\
\text { oxokaur-16-en-19-oic }\end{array}$ \\
\hline 387.18203 & {$\left[\mathrm{C}_{22} \mathrm{H}_{27} \mathrm{O}_{6}-\mathrm{H}\right]^{-}$} & $-2,10$ & $\cdots$ \\
\hline 399.15823 & {$\left[\mathrm{C}_{20} \mathrm{H}_{28} \mathrm{O}_{6}+\mathrm{Cl}\right]^{-}$} & $-0,59$ & $\begin{array}{c}(1 \beta, 5 \beta, 9 \xi, 10 \alpha, 11 \alpha, 13 \alpha, 14 S)-1,11,14,20 \text {-tetrahydroxy- } \\
7,20 \text {-epoxykaur-16-en-15-ona }\end{array}$ \\
\hline 421.18788 & {$\left[\mathrm{C}_{22} \mathrm{H}_{29} \mathrm{O}_{8}-\mathrm{H}\right]^{-}$} & $-2,59$ & $\cdots$ \\
\hline
\end{tabular}

The EO of Copaifera spp. analyzed by GC/MS had many sesquiterpenes in its chemical composition; $96.16 \%$ of the identified components were sesquiterpene hydrocarbons, with $\beta$-caryophyllene as the major component (35.03\%), followed by $\alpha$-copaene (33.61\%) (Table 2$)$. 
Table 2. Chemical composition of the essential oil (EO) of Copaifera spp. analyzed by gas chromatography coupled with mass spectrometry (GC/MS).

\begin{tabular}{|c|c|c|}
\hline Constituents & KI (Kovats Index) & $\begin{array}{l}\text { Relative percentage (\%) of constituents of } \\
\text { the essential oil (EO) }\end{array}$ \\
\hline \multicolumn{3}{|l|}{ Sesquiterpene hydrocarbons } \\
\hline$\delta$-elemene & 1338 & 0.27 \\
\hline$\alpha$-cubebene & 1348 & 3.80 \\
\hline$\alpha$-copaene & 1376 & 33.61 \\
\hline$\beta$-cubebene & 1388 & 1.44 \\
\hline$\beta$-elemene & 1390 & 2.14 \\
\hline Cyperene & 1398 & 0.21 \\
\hline$\beta$-caryophyllene & 1419 & 35.03 \\
\hline$\gamma$-elemene & 1436 & 0.60 \\
\hline$\alpha$-trans-bergamotene & 1434 & 1.33 \\
\hline$\alpha$-humulene & 1454 & 4.33 \\
\hline Aromadendrene & 1460 & 2.23 \\
\hline$\gamma$-muurolene & 1479 & 0.61 \\
\hline cadina-1(6),4-diene $<$ cis $>$ & 1463 & 1.11 \\
\hline$\alpha$-muurolene & 1500 & 0.34 \\
\hline$\beta$-bisabolene & 1505 & 0.40 \\
\hline$\gamma$-cadinene & 1513 & 2.46 \\
\hline$\delta$-cadinene & 1523 & 4.18 \\
\hline$\alpha$-cadinene & 1538 & 0.18 \\
\hline \multirow[t]{2}{*}{ Germacrene B } & 1561 & 1.89 \\
\hline & & 96.16 \\
\hline Oxygenated sesquiterpenes & $\cdots$ & -- \\
\hline Unidentified compounds & $\cdots$ & 3.84 \\
\hline TOTAL & $-\cdots$ & 100 \\
\hline
\end{tabular}

Seventy-seven cows were tested using a strip cup and the CMT. Of those, 33 were healthy, one had clinical mastitis, and 43 had subclinical mastitis ranging from grades I to III. Twenty-four cows had grade III subclinical mastitis, and milk samples were collected from 36 teats for microbiological evaluation.

After cultivation, there was no yeast proliferation, and 60 bacteria were classified. Frequencies were $36.6 \%$ (22/60) of coagulase-negative Staphylococcus (CNS); 26.7\% (16/60) of S. aureus; $6.7 \%(04 / 60)$ of Corynebacterium spp.; 5.0\% (03/60) of Streptococcus of groups C, F, and G; $5.0 \%(03 / 60)$ of Staphylococcus schleiferi schleiferi; 3.3\% (02/60) of Escherichia coli; 3.3\% (02/60) of Staphylococcus hyicus; 3.3\% (02/60) of Staphylococcus schleiferi coagulans; 3.3\% (02/60) of Leuconostoc spp.; 1.7\% (01/60) of Staphylococcus intermedius; 1.7\% (01/60) of Acinetobacter spp.; 1.7\% (01/60) of Sphingomonas paucimobilis; and 1.7\% (01/60) of Stomatococcus spp. 
The antimicrobial activity of the EO and the OR of Copaifera spp. was tested against CNS, coagulasepositive Staphylococcus (CPS: S. aureus, S. schleiferi schleiferi, S. hyicus, S. schleiferi coagulans, and S. intermedius), Corynebacterium spp., Streptococcus of groups C, F, and G, and Escherichia coli. The MIC test was not carried out for bacteria identified as Leuconostoc spp., Acinetobacter spp., Sphingomonas paucimobilis and Stomatococcus spp. because these are isolated etiological agents with low frequency in bovine mastitis.

For the CNS, the MIC of the EO of Copaifera spp. was $\leq 100 \mu \mathrm{g} / \mathrm{mL}$ for $9.1 \%(02 / 22)$ of the samples, 125 $\mu \mathrm{g} / \mathrm{mL}$ for $9.1 \%(02 / 22), 1000 \mu \mathrm{g} / \mathrm{mL}$ for $22.7 \%(05 / 22)$, and $>1000 \mu \mathrm{g} / \mathrm{mL}$ for the remaining $59.1 \%(13 / 22)$ (Table 3). Using the OR against the same bacteria, the MIC was $\leq 100 \mu \mathrm{g} / \mathrm{mL}$ for $40.9 \%(9 / 22), 1000 \mu \mathrm{g} / \mathrm{mL}$ for $31.8 \%(7 / 22)$, and $>1000 \mu \mathrm{g} / \mathrm{mL}$ for the remaining $27.3 \%(6 / 22)$ of the isolates (Table 3$)$.

Table 3. Minimum Inhibitory Concentration of the essential oil (EO) and oleoresin (OR) of Copaifera spp. against coagulase-negative Staphylococcus (CNS) isolated from milk samples of cows diagnosed with grade III subclinical mastitis

\begin{tabular}{ccc}
\hline Microorganisms & MIC $(\mu \mathrm{g} / \mathrm{mL})$ & MIC $(\mu \mathrm{g} / \mathrm{mL})$ \\
\hline CNS & Copaifera spp. EO & Copaifera spp. OR \\
\hline$(1)$ & $>1000$ & $>1000$ \\
$(2)$ & $>1000$ & $>1000$ \\
$(3)$ & $>1000$ & 1000 \\
$(4)$ & $>1000$ & 62.5 \\
$(5)$ & $>1000$ & 1000 \\
$(6)$ & $>1000$ & $>1000$ \\
$(7)$ & 1000 & 1000 \\
$(8)$ & $>1000$ & 31.25 \\
$(9)$ & $>1000$ & 15.62 \\
$(10)$ & $>1000$ & 1000 \\
$(11)$ & $>1000$ & $>1000$ \\
$(12)$ & 1000 & 7.81 \\
$(13)$ & $>1000$ & $>1000$ \\
$(14)$ & 1000 & 7.81 \\
$(15)$ & 1000 & 3.90 \\
$(16)$ & 1000 & 7.81 \\
$(17)$ & $>1000$ & $>1000$ \\
$(18)$ & $>1000$ & 15.62 \\
$(19)$ & 125 & 1000 \\
$(20)$ & 62.5 & 1000 \\
$(21)$ & 125 & 1000 \\
$(22)$ & 15.62 & 31.25 \\
\hline & &
\end{tabular}

The MIC values of the EO of Copaifera spp. for the isolates of $S$. aureus were $1000 \mu \mathrm{g} / \mathrm{mL}$ for $37.5 \%$ of the samples (6/16) and $>1000 \mu \mathrm{g} / \mathrm{mL}$ for $62.5 \%$ (10/16). For S. schleiferi schleiferi (3/3), S. hyicus (2/2), S. schleiferi coagulans (2/2), and $S$. intermedius (1/1), the MIC was $>1000 \mu \mathrm{g} / \mathrm{mL}$ (Table 4). 
Table 4. Minimum Inhibitory Concentration of the essential oil (EO) and oleoresin (OR) of Copaifera spp. against coagulase-positive Staphylococcus (CPS) isolated from milk samples of cows diagnosed with grade III subclinical mastitis

\begin{tabular}{|c|c|c|}
\hline Microorganisms & MIC $(\mu \mathrm{g} / \mathrm{mL})$ & MIC $(\mu \mathrm{g} / \mathrm{mL})$ \\
\hline CPS & Copaifera spp. EO & Copaifera spp. OR \\
\hline \multicolumn{3}{|l|}{ S. aureus } \\
\hline (1) & 1000 & 31.25 \\
\hline (2) & $>1000$ & 15.62 \\
\hline (3) & $>1000$ & 15.62 \\
\hline (4) & $>1000$ & 15.62 \\
\hline (5) & 1000 & 7.81 \\
\hline (6) & $>1000$ & 7.81 \\
\hline (7) & $>1000$ & 31.25 \\
\hline (8) & $>1000$ & 15.62 \\
\hline (9) & $>1000$ & 125 \\
\hline (10) & $>1000$ & 500 \\
\hline (11) & 1000 & 7.81 \\
\hline (12) & $>1000$ & 31.25 \\
\hline (13) & 1000 & 7.81 \\
\hline (14) & 1000 & 1.95 \\
\hline (15) & 1000 & 31.25 \\
\hline (16) & $>1000$ & 15.62 \\
\hline \multicolumn{3}{|c|}{ S. schleiferi schleiferi } \\
\hline (1) & $>1000$ & 62.5 \\
\hline (2) & $>1000$ & 62.5 \\
\hline (3) & $>1000$ & 62.5 \\
\hline \multicolumn{3}{|l|}{ S. hyicus } \\
\hline (1) & $>1000$ & 62.5 \\
\hline (2) & $>1000$ & 31.25 \\
\hline \multicolumn{3}{|l|}{ S. schleiferi coagulans } \\
\hline (1) & $>1000$ & 31.25 \\
\hline (2) & $>1000$ & 250 \\
\hline \multicolumn{3}{|l|}{ S. intermedius } \\
\hline (1) & $>1000$ & 31.25 \\
\hline
\end{tabular}

The OR of Copaifera spp. had MIC $\leq 100 \mu \mathrm{g} / \mathrm{mL}$ against $87.5 \%(14 / 16)$ of the $S$. aureus isolates. For two isolates, $S$. aureus numbers (9) and (10), MIC values were $125 \mu \mathrm{g} / \mathrm{mL}$ and $500 \mu \mathrm{g} / \mathrm{mL}$, respectively. MIC values against $S$. schleiferi schleiferi (3/3), S. hyicus (2/2), S. schleiferi coagulans (1/2), and S. intermedius $(1 / 1)$ were $\leq 100 \mu \mathrm{g} / \mathrm{mL}$, except for $S$. schleiferi coagulans number (2), where the MIC was $250 \mu \mathrm{g} / \mathrm{mL}$, as seen in Table 4.

When the antimicrobial activity was tested against bacteria in genus Corynebacterium, the MIC value of the EO of Copaifera spp. was $\leq 100 \mu \mathrm{g} / \mathrm{mL}$ for $25 \%(1 / 4)$, but $1000 \mu \mathrm{g} / \mathrm{mL}$ for $50 \%(2 / 4)$, and $>1000 \mu \mathrm{g} / \mathrm{mL}$ for $25 \%$ (1/4) of the remaining isolates. The MIC of the OR of Copaifera spp. was $\leq 100 \mu \mathrm{g} / \mathrm{mL}$ for $75 \%(3 / 4)$ of the same bacteria, and $125 \mu \mathrm{g} / \mathrm{mL}$ for $25 \%(1 / 4)$. 
The EO of Copaifera spp. had antimicrobial activity against Streptococcus of groups C, F, and G, with MIC values of $1000 \mu \mathrm{g} / \mathrm{mL}$ for $33.3 \%(1 / 3)$ of the samples and $>1000 \mu \mathrm{g} / \mathrm{mL}$ for $66.7 \%(2 / 3)$. Using the OR against the same bacteria resulted in a MIC $\leq 100 \mu \mathrm{g} / \mathrm{mL}$ for $66.7 \%(2 / 3)$ and $1000 \mu \mathrm{g} / \mathrm{mL}$ for $33.3 \%$ (1/3) of the bacteria.

The MIC values for the EO of Copaifera spp. regarding the antimicrobial activity against Escherichia coli $(2 / 2)$ were $1000 \mu \mathrm{g} / \mathrm{mL}$ and $>1000 \mu \mathrm{g} / \mathrm{mL}$, while the OR had MIC $>1000 \mu \mathrm{g} / \mathrm{mL}$ against the same samples.

\section{Discussion}

According to Brito et al. ${ }^{(26)}$, bacteria in genus Staphylococcus are prominent in the etiology of intramammary infections of dairy cattle in Brazil. The same was observed in our results, where this genus predominated. The most common etiological agents were CNS and S. aureus, with frequencies of $36.6 \%$ and $26.7 \%$, respectively.

The antimicrobial activity of the OR of Copaifera spp. against CPS was good in $87.5 \%(21 / 24)$ of the samples, in contrast to the EO, which was inactive in $75 \%(18 / 24)$ of the samples. Thus, CPS were more sensitive to the OR than the EO of Copaifera spp. These results corroborate the study of Santos et al. ${ }^{(16)}$, who found that the OR of Copaifera martii, Copaifera officinalis, and Copaifera reticulata had good antibacterial activity (MIC ranging from 31.3 to $62.5 \mu \mathrm{g} / \mathrm{mL}$ ) against Grampositive bacteria ( $S$. aureus, methicillin-resistant $S$. aureus, Staphylococcus epidermidis, Bacillus subtilis, and Enterococcus faecalis), with lower bacterial viability after 3 hours.

The EO of Copaifera spp. had a good antimicrobial activity against 9.1\% (02/22) of the CNS, but the OR had better antimicrobial effects against the same bacteria, with $40.9 \%(9 / 22)$. Therefore, CNS were also more sensitive to the OR than the EO of Copaifera spp. Current studies focused on CNS aim to reduce lineages resistant to antibiotics used in the treatment of mastitis. For example, Pereira et al. ${ }^{(27)}$ demonstrated good antimicrobial activity of ethanol extracts of the bark of black jurema (Mimosa tenuiflora (Wild) Poiret- Leguminosae) and leaves of neem (Azadirachta indica A. Juss- Meliaceae) against CNS isolated from subclinical mastitis in buffaloes.

The EO of Copaifera spp. had good antimicrobial activity against 25\% (1/4) of Corynebacterium spp., but the OR had a better antimicrobial effect, against 75\% (3/4). No previous tests of antimicrobial activity of the EO and OR of Copaifera spp. against Corynebacterium spp. were found in the literature; however, we observed higher sensitivity to the OR than to the EO of Copaifera spp.

For Streptococcus of groups C, F, and G, the OR of Copaifera spp. also had a good antimicrobial activity against $66.7 \%(2 / 3)$ of the samples, unlike the EO of Copaifera spp., which was inactive against $66.7 \%(2 / 3)$. Thus, Streptococcus of groups C, F, and G had higher sensitivity to the OR than the EO of Copaifera spp. Other studies demonstrated that the OR of copaiba was active against bacteria in genus Streptococcus. For instance, Pieri et al. ${ }^{(28)}$ showed in vitro antimicrobial activity of a solution of copaiba (Copaifera officinalis) against the oral microorganisms Streptococcus mutans, Streptococcus salivarius, Streptococcus pyogenes, and Enterococcus faecalis. These studies suggest that the OR of copaiba is a potential alternative for orthodontic treatments.

In contrast to the other results, the antimicrobial activities of the EO and the OR of Copaifera spp. 
against Escherichia coli were weak to inactive and inactive, respectively. Other studies found resistance of Gram-negative bacteria, including E. coli and Pseudomonas aeruginosa, to the OR of copaiba $^{(16,29,30)}$, corroborating our results.

Overall, the OR of Copaifera spp. had better antimicrobial activity $(63.7 \%, 35 / 55)$ than the EO $(5.5 \%, 3 / 55)$ against the 55 bacteria identified from milk samples of cows diagnosed with grade III subclinical mastitis $(\mathrm{p}<0.0001)$. Pieri et al. ${ }^{(31)}$ suggested that the copaiba OR has different components that act synergistically in many structures and metabolic paths of the bacterial cells, which may explain the results of our study.

According to Table 1, we identified sesquiterpenes, diterpenes, and the compounds with 22 atoms of carbon in the OR from Copaifera spp. samples. The sesquiterpens and diterpenes are formed by 15 and 20 carbon atoms, respectively ${ }^{(32)}$. While the compounds containing 22 atoms of carbon are suggestive as diterpenes esterified with ethyl or acetyl.

According to Veiga Júnior and Pinto ${ }^{(10)}$, the 28 diterpenes described in OR from copaiba which were studied belong to cauran, labdan, and clerodan skeletons. Only two cauran have been described in scientific literature: ent-caura-16-eno-19-oic acid, which has also been found in the study samples, and ent-16- $\beta$-cauran-19-oic acid. By the ESI(-) FT-ICR MS method, used in this study, we could identify two more cauran in the OR from Copaifera spp.: $(5 \beta, 7 \alpha, 8 \alpha, 9 \beta, 10 \alpha$, $13 \alpha, 14 \mathrm{R})$-7,14-dihydroxy-15-oxokaur-16-en-19-oic (Table 1) and $(1 \beta, 5 \beta, 9 \xi, 10 \alpha, 11 \alpha, 13 \alpha, 14 \mathrm{~S})$ -1,11,14,20-tetrahydroxy-7,20-epoxikaur-16-en-15-ona (Table 1).

Veiga Júnior et al. ${ }^{(33)}$ and Veiga Júnior and Pinto ${ }^{(10)}$ argued that diterpene acids contribute for most of the therapeutic properties of the OR, and that antimicrobial activity can be explained by the presence of kaurenoic acid. Thus, the antimicrobial effect of the OR may be caused by diterpene acids, which can act synergistically with other components.

Antimicrobial activity of essential oils and their isolated constituents are related to chemical characteristics, functional and stereochemical groups of constituents, as well as with oxygenated compounds present in essential oils, particularly, those with fenolic structure (carvacrol, eugenol, timol), aliphatic terpenoids with ester grouping (geranyl acetate), alcohol (linalol) or aldheyde (cinamaldheyde), which are highlighted for their potential antimicrobial effect $^{(34)}$.

The EO, volatile fraction of OR from Copaifera spp., is constituted by oxygenated and hydrocarbon sesquiterpenes $^{(10)}$. The EO from Copaifera spp. in this study presented hydrocarbons sesquiterpenes as the majority of compounds, with $96.16 \%$. By taking into account the study by Henriques et al. ${ }^{(34)}$, this fact would justify the weak and inactive EO antimicrobial activity.

The chemical compounds present in the EO in our study (Table 2) were similar to those found by other authors ${ }^{(12,15,17,35)}$. Both Veiga Júnior and Pinto ${ }^{(10)}$ and Pieri et al. ${ }^{(36)}$ attributed the antiinflammatory, antibacterial, antifungal and anti-edema activities of the OR of copaiba to the sesquiterpene $\beta$-caryophyllene, which was the major component of the volatile fraction in the present study.

Although there are records in the literature of antimicrobial activity of $\beta$-caryophyllene, Souza et al. ${ }^{(37)}$ demonstrated that the isolated caryophyllene compound had no antifungal activity, suggesting that certain phytochemicals only have an antimicrobial effect when they act synergistically with other components. Thus, the synergic functions of the various molecules found in the essential oils seem questionable compared to the effect of one or two compounds isolated from the oil ${ }^{(38)}$. 
Despite the different pharmacological activities recorded for the copaiba OR and the number of substances identified, little is known about the link between chemical structure and activity of each component $^{(35)}$. For Tappin et al. ${ }^{(39)}$, the OR of copaiba is an example where the full chemical profile, in addition to the characterization of the species present, is more important than isolated substances in determining putative pharmacological activities.

\section{Conclusions}

In general, the OR of Copaifera spp. had good antimicrobial activity against the main pathogens that cause bovine mastitis, making this a promising raw plant material for the development of phytotherapeutic drugs to treat this disease. However, more studies are needed to better understand the connection between the chemical structure and the biological activities of its components.

\section{Acknowledgments}

To the funding agencies CAPES, CNPq and FAPEG-GO.

\section{References}

1. Ribeiro Júnior E, Silva MH, Viegas SAA, Ramalho EJ, Ribeiro MD, Oliveira FCS. Califórnia mastitis test (CMT) e whiteside como métodos de diagnóstico indireto da mastite subclínica. Rev. Bras. Saúde Prod. An. 2008; 9 (4): 680- 686.

2. Freitas MFL, Pinheiro Júnior JW, Stamford TLM, Rabelo SSA, Silva DR, Silveira Filho VM, Santos FGB, Sena MJ, Mota RA. Perfil de sensibilidade antimicrobiana in vitro de Staphylococcus coagulase positivos isolados de leite de vacas com mastite no Agreste do Estado de Pernambuco. Arq. Inst. Biol. 2005; $72(2): 171-177$.

3. Prestes DS, Filappi A, Cecim M. Susceptibilidade à mastite: fatores que a influenciam- uma revisão. Revista da FZVA. 2002; 9 (1): 118-132.

4. Guimarães FF, Langoni H. Leite: alimento imprescindível, mas com risco para saúde pública. Veterinária e Zootecnia. 2009; 16 (1): 38- 51.

5. Voltolini TV, Santos GT, Zambom MA, Ribas NP, Müller EE, Damasceno JC, Ítavo LCV, Veiga DR. Influência dos estádios de lactação sobre a contagem de células somáticas do leite de vacas da raça holandesa e identificação de patógenos causadores de mastite no rebanho. Acta Scientiarum. 2001; 23 (4): 961-966.

6. Oliveira MCS. Doenças Infecciosas em sistema intensivo de produção de leite. Embrapa Pecuária Sudeste, São Carlos, 2006. p. 34.

7. Sá MEP; Cunha MLRS, Elias AO, Victória C, Langoni H. Importância do Staphylococcus aureus nas mastites subclínicas: pesquisa de enterotoxinas e toxina do choque tóxico, e a relação com a contagem de células somáticas. Braz J vet Res anim Sci. 2004; 41 (5): 320-326. 
8. Almeida LAB, Brito MAVP, Brito JRF, Pires MFÁ, Benites, NR. Tratamento de mastite clínica experimental por meio de ordenhas múltiplas em vacas leiteiras inoculadas com Staphylococcus aureus. Arq. Inst. Biol. 2005; 72 (1): 1-6.

9. Braga MD, Silva CCM. Atividade antimicrobiana do extrato aquoso de Copaifera langsdorffii Desf. sobre Staphylococcus aureus. Unimontes Científica. 2007; 9 (1): 91-97.

10. Veiga Júnior VF, Pinto AC. O gênero Copaifera L. Quim. Nova. 2002; 25 (2): 273-286.

11. Biavatti MW, Dossin D, Deschamps FC, Lima MP. Análise de óleos-resinas de copaíba: contribuição para o seu controle de qualidade. Revista Brasileira de Farmacognosia. 2006; 16 (2): 230-235.

12. Veiga Júnior VF, Rosas EC, Carvalho MV, Henriques MGMO, Pinto AC. Chemical composition and anti-inflammatory activity of copaiba oils from Copaifera cearensis Huber ex Ducke, Copaifera reticulata Ducke and Copaifera multijuga Hayne- A comparative study. Journal of Ethnopharmacology. 2007; 112: 248-254.

13. Martins IFB, Silva A. Influência do óleo de copaíba (Copaifera sp.) no tratamento de ferida cutânea infeccionada. R. pesq.: cuid. fundam. online. 2010; 2(Ed. Supl.): 526-529.

14. Mendonça DE, Onofre SB. Atividade antimicrobiana do óleo-resina produzido pela copaíba- Copaifera multijuga Hayne (Leguminosae). Revista Brasileira de Farmacognosia. 2009; 19 (2B): 577-581.

15. Vasconcelos KRF, Veiga Júnior VF, Rocha WC, Bandeira MFCL. Avaliação in vitro da atividade antibacteriana de um cimento odontológico à base de óleo-resina de Copaifera multijuga Hayne. Revista Brasileira de Farmacognosia. 2008; 18 (Supl.): 733-738.

16. Santos AO, Ueda-Nakamura T, Filho BPD, Veiga Junior VF, Pinto AC, Nakamura CV. Antimicrobial activity of Brazilian copaiba oils obtained from different species of the Copaifera genus. Mem Inst Oswaldo Cruz. 2008; 103 (3): 277-281.

17. Deus RJA, Alves CN, Arruda MSP. Avaliação do efeito antifúngico do óleo resina e do óleo essencial de copaíba (Copaifera multijuga Hayne). Rev. Bras. Pl. Med. 2011; 13 (1): 1-7.

18. Bulgacov A, Silva LC, Júnior FAB, Teixeira TG. Susceptibilidade de Staphylococcus spp. ao óleo de copaíba, cloranfenicol ou enrofloxacinaem cepas isolados de casos de mastite subclínica em vacas de leite. Revista Investigação Medicina Veterina, 2015; 14 (2): 90-95.

19. Ferreira FPS, Morais SR, Bara MTF, Conceicão EC, Paula JR, Carvalho TC, Vaz BG, Costa HB, Romão W, Rezende MH. Eugenia calycina Cambess extracts and their fractions: Theirantimicrobial activity and the identification of major polarcompounds using electrospray ionization FT-ICR mass spectrometry. Journal of Pharmaceutical and Biomedical Analysis. 2014; 99: 89- 96.

20. Adams RP. Identification of essential oil components by Gas Chromatography/Mass Spectrometry. 4th ed. Carol Stream, Illinois: Allured Publishing Corporation. 2007.

21. Winn W, Allen S, Janda W, Koneman E, Procop G, Schreckenberger P, Woods G. Diagnóstico Microbiológico, $6^{\circ}$ ed., Guanabara Koogan, Rio de Janeiro, 2008.

22. Baron EJ, Peterson IR, Finegold SM. Diagnostic microbiology. 7. ed. Mosby: Missouri, 1994. p. 914.

23. Brasil. Agência Nacional de Vigilância Sanitária (ANVISA). Detecção e Identificação de Bactérias de Importância Médica. Módulo V. 2004.

24. CLSI- Clinical and Laboratory Standards Institute. Methods for Dilution Antimicrobial Susceptibility Tests for Bacteria That Grow Aerobically. Approved Standard- Sixth Edition. NCCLS document M7-A6 (ISBN 1-56238-486-4). NCCLS, 940 West Valley Road, Suite 1400, Wayne, Pennsylvania 19087-1898 USA, 2003. p. 81. 
25. Holetz FB, Pessini GL, Sanches NR, Cortez DAG, Nakamura CV, Filho BPD. Screening of some plants used in the brazilian folk medicine for the treatment of infectious diseases. Mem. Inst. Oswaldo Cruz. 2002; 97 (7): 1027-1031.

26. Brito MAVP, Campos GMM, Brito JRF. Esquema simplificado para identificação de Estafilococos coagulase-positivos isolados de mastite bovina. Ciência Rural. 2002; 32 (1): 79-82.

27. Pereira AV, Lôbo KMS, Bezerra DAC, Rodrigues OG, Athayde ACR, Mota RA, De Lima EQ, Medeiros ES. Perfil de sensibilidade antimicrobiana in vitro de jurema preta e nem sobre amostras de Staphylococcus spp. isoladas de mastite em búfalas. Arq. Inst. Biol. 2009; 76 (3): 341-346.

28. Pieri FA, Mussi MC, Fiorini JE, Schneedorf JM. Efeitos clínicos e microbiológicos do óleo de copaíba (Copaifera officinalis) sobre bactérias formadoras de placa dental em cães. Arq. Bras. Med. Vet. Zootec. 2010; 62 (3): 578-585.

29. Pacheco TARC, Barata LES, Duarte MCT. Antimicrobial activity of copaiba (Copaifera spp.) balsams. Rev. Bras. Pl. Med. 2006; 8 (esp.): 123-124.

30. Packer JF, Luz MMS. Método para avaliação e pesquisa da atividade antimicrobiana de produtos de origem natural. Revista Brasileira de Farmacognosia. 2007; 17 (1): 102-107.

31. Pieri FA, Souza CF, Costa JCM, Barrero MAO; Espeschit IF, Silva VO, Moreira MAS. Inhibition of Escherichia coli from mastitic milk by copaiba oil. Semina: Ciências Agrárias. 2011; 32 (Suppl. 1): 19291934.

32. Simões CMO, Spitzer V. Óleos voláteis. In: Simões CMO, Schenkel EP, Gosmann G, Mello JCP, Mentz LA, Petrovick PR. Farmacognosia: da planta ao medicamento. 6 ed. Florianópolis: Editora da UFSC, 2010. p. 1102.

33. Veiga Júnior VF, Patitucci ML, Pinto AC. Controle de autenticidade de óleos de copaíba comerciais por cromatografia gasosa de alta resolução. Quim. Nova. 1997; 20 (6): 612-615.

34. Henriques AT, Simões-Pires CA, Apel MA. Óleos essenciais: importância e perspectivas terapêuticas. In: Yunes $\mathrm{R}$ A, Cechimel Filho $\mathrm{V}$. Química de produtos naturais, novos fármacos e a moderna farmacognosia. 2 ed. Itajaí: Universidade do Vale do Itajaí, 2009.

35. Cascon V, Gilbert B. Characterization of the chemical composition of oleoresins of Copaifera guianensis Desf., Copaifera duckei Dwyer and Copaifera multijuga Hayne. Phytochemistry. 2000; 55: 773-778.

36. Pieri FA, Mussi MC, Moreira MAS. Óleo de copaíba (Copaifera sp.): histórico, extração, aplicações industriais e propriedades medicinais. Rev. Bras. Pl. Med.. 2009; 11 (4): 465-472.

37. Souza EL, Lima EO, Freire KRL, Sousa CP. Inhibitory action of some essential oils and phytochemicals on the growth of various moulds isolated from foods. Brazilian Archives of Biology and Technology- an International Journal. 2005; 48: (2) 245-250.

38. Bakkali F, Averbeck S, Averbeck D, Idaomar M. Biological effects of essential oils - A review. Food and Chemical Toxicology. 2008; 46: 446-475.

39. Tappin MRR, Pereira JFG, Lima LA, Siani AC, Mazzei JL, Ramos MFS. Análise química quantitativa para a padronização do óleo de copaíba por cromatografia em fase gasosa de alta resolução. Quim. Nova. 2004; 27 (2): 236-240. 